\title{
Teori Nasakh Mansukh Dalam Penetapan Hukum Syariat Islam
}

\author{
Muhammad Husni dan Fathul Wahab \\ Institut Agama Islam Al-Qolam Malang \\ Email: husninanang73@gmail.com
}

\begin{abstract}
The existence of nasakh and mansukh in the determination of Islamic law is very important, because not always the law in one place is the same as the place and conditions in other places. It's just that in imposing nasakh and mansukh this is limited to the problems of shar'i law, while other than that it is not permissible such as the issue of aqidah or the points of worship and moral principles, such as justice, honesty, prohibition of shirk, killing, stealing and others etc .. Besides that, the determination of nasakh and mansukh is not permitted by using ijtihad or the opinions of the scholars, but it is indeed pure from Allah Almighty contained in the Qur'an. However, there are two opposing groups namely those who support the existence of nasakh and mansukh in the Qur'an and groups who reject the existence of nasakh and mansukh in the Qur'an. The middle way taken is to compromise the two opposing groups by reviewing the terms understanding nasakh and mansukh. With this compromise, it is hoped that there will be no more opposition regarding nasakh and mansukh. For this reason the scholars set ways to know nasakh and mansukh strictly. Despite the pros and cons of nasakh and mansukh. Nasakh and mansukh have provided great lessons for Muslims including the development of tasyri 'towards the level and the desire for goodness and convenience for Muslims.
\end{abstract}

\section{Keywords: Mansukh Nasakh, Islamic Sharia Law}

\begin{abstract}
Abstrak: Keberadaan nasakh dan mansukh dalam penetapan hukum Islam sangat penting, karena tidak selamanya hukum dalam satu tempat sama dengan tempat dan kondisi di lain tempat. Hanya saja dalam memberlakukan nasakh dan mansukh ini terbatas pada masalah-masalah hukum syar'i, sementara selain itu tidak diperbolehkan seperti masalah aqidah atau pokok-pokok ibadah dan pokokpokok akhlaq, seperti keadilan, kejujuran, larangan syirik, membunuh, mencuri dan lain sebagainya.. Disamping itu penetapan nasakh dan mansukh tidak diperkenankan dengan menggunakan ijtihad atau pendapat dari para ulama, tetapi memang murni dari Allah swt yang terdapat di dalam Al Qur'an. Namun begitu, terdapat dua golongan yang berlawanan yaitu golongan yang mendukung adanya nasakh dan mansukh di dalam Al Qur'an dan golongan yang menolak adanya nasakh dan mansukh dalam Al Qur'an. Jalan tengah yang diambil adalah dengan jalan mengkompromikan kedua golongan yang bersebrangan dengan meninjau kembali istilah pengertian nasakh dan mansukh. Dengan adanya kompromi ini diharapkan tidak ada lagi pertentangan mengenai nasakh dan mansukh. Karena itulah para ulama menetapkan cara-cara untuk mengetahui
\end{abstract}


nasakh dan mansukh secara ketat. Meskipun terjadi pro kontra terhadap nasakh dan mansukh. Nasakh dan mansukh telah memberikan hikmah yang besar bagi umat Islam diantaranya adalah Perkembangan tasyri menuju tingkat dan menghendaki kebaikan dan kemudahan bagi umat Islam.

Kata Kunci: Nasakh Mansukh, Hukum Syariat Islam

Al Qur'an merupan sumber hukum utama dalam Islam. Sebagai sumber utama Al Qur'an bersifat baku dan universal artinya keberadaan Al Qur'an tetap orsinil sepanjang masa dan tidak mengalami perubahan sedikitpun baik dari segi bahasa maupun dari segi makna. Al Qur'an selalu up to date terhadap perkembangan zaman, ini bukan berarti Al Qur'an menyesuaikan diri dengan perkembangan zaman, akan tetapi Al Qur'an menjadi barometer bagi perkembangan zaman yang ditandai dengan kemajuan sains dan teknologi. Perkembangan sains dan teknologi sebagai puncak kebudayaan manusia harus menyelaraskan diri dengan $\mathrm{Al}$ Qur'an sehingga memiliki manfaat besar bagi kehidupan manusia. Kebudayaan yang menyelaraskan diri dengan Al Qur'an maka kebudayaan tersebut akan mengandung nilai-nilai kemanusian yang tinggi. Sedangkan Al Qur'an bersifat universal artinya bahwa syariat yang ditetapkan Al Qur'an berlaku untuk seluruh manusia yang tidak tersekat antara waktu dan ruang. Namun demikian hukumhukum Al Qur'an kebanyakan masih bersifat mujmal yang membutuhkan interpretasi dari para ulama. Meskipun interpretasi yang dilakukan oleh ulama tersebut terkadang terjadi perbedaan pandangan antara satu dengan yang lainnya. Perbedaan pandangan adalah rahmat, yang menurut Imam Taufiq, menunjukkan beragamnya cara pandang manusia sebagai makhluk yang berakal, memahami simbul, intelek, berilmu pengetahuan dan normatif. (Imam Taufiq, 2001, p.135) Sebagai hukum utama dalam Islam, kajian terhadap Al Qur'an terus dilakukan oleh para ulama. Karena Al Qur'an tidak hanya sumber hukum tetapi juga sumber ilmu pengetahuan karena apabila semakin dikaji dan digali maka semakin dalam arti Al Qur'an itu sendiri. Kajian tehadap Al Qur'an tidak hanya terbatas pada masalahmasalah hubungan ayat satu dengan ayat lain, tempat diturunkannya ayatayat tersebut, tetapi juga ayat-ayat yang berkaitan dengan printah dan larangan yang di dalamnya mengandung nasakh dan mansukh. Keberadaan nasakh dan mansukh itu sendiri telah menyebabkan terjadi perbedaan pandangan di kalangan ulama. Ada golongan ulama yang menerima nasakh dan mansukh itu sebagai dalam pemberlakuan hukum syariat. Ada pula golongan ulama yang menolok nasakh dan mansukh

$$
\text { Nasakh dan mansukh }
$$

merupakan issu sentral dalam pembahasan makalah ini, karena 
memahami Al Qur'an tidak terlepas dari permasalahan nasakh dan mansukh apalagi menyangkut permasalahan dalam menetapkan hukum.

\section{Pengertian}

Secara etimologis, kata naskh yang bentuk isim failnya "nasikh" dan isim maf 'ulnya "mansukh", mempunyai arti yang beragam, antara lain : menghilangkan, menghapuskan, membatalkan. Yang berarti membatalkan atau memindah dari satu wadah ke wadah yang lain. Atau juga berarti penukilan dan penyalinan, (Quraish Shihab, 1994, p.143) penghapusan/pembatalan (alizalah atau al-ibthal), pemindahan (al-naql), pengubahan/penggantian (al-ibdal), dan pengalihan (al-tahwil atau al-intiqal). ${ }^{5}$ Berkaitan dengan pengertian tersebut, maka nasikh (isim fa ${ }^{\prime} i l$ ) diartikan sesuatu yang membatalkan, menghapus, memindahkan, dan memalingkan. Sedangkan mansukh (isim maful) adalah sesuatu yang dibatalkan, dihapus, dipindahkan, diganti, dan dipalingkan. Terdapat perbedaan pendapat antara ulama mutaqaddimin dan mutaakhirin dalam mendefinisikan nasakh secara terminologis. Perbedaan pendapat tersebut bersumber pada banyaknya pengertian nasakh secara etimologi sebagaimana dijelaskan di atas. Cakupan makna yang ditetapkan ulama mutaqoddimin di antaranya: 1) Pembatalan hukum yang ditetapkan sebelumnya dengan hukum yang ditetapkan kemudian;

Pengecualian/pengkhususan hukum bersifat `am/umum oleh hukum yang lebih khusus yang datang setelahnya; 3) Bayan atau penjelasan yang datang kemudian terhadap hukum yang bersifat samar; 4) Penetapan syarat terhadap hukum terdahulu yang belum bersyarat (Moh. Nor Ichwan, p.108)

Di samping itu ada yang berpendapat bahwa istilah tersebut berarti pembatalan ketetapan hukum yang ditetapkan pada suatu kondisi tertentu oleh ketetapan lain yang berbeda akibat munculnya kondisi lain. Misalnya perintah agar kaum muslimin pada periode Mekkah bersabar karena lemah telah dinasakh oleh adanya perintah berperang pada periode Madinah karena kondisi mereka sudah kuat. Bahkan ketetapan hukum Islam yang membatalkan hukum yang berlaku pada masa sebelum Islam termasuk dalam pengertian nasakh (Dewan Redaksi Enskopedi Islam, 1997, p.16) Sementara menurut ulama mutaakhirin, nasakh adalah dalil yang datang kemudian, berfungsi untuk menggugurkan dan menghilangkan hukum yang pertama (Quraish Shihab, 2004, p.143) Dengan demikian ulama mutaakhirin mempersempit pengertian yang luas itu. Menurut mereka, nasakh adalah ketentuan hukum yang datang kemudian untuk membatalkan masa berlakunya hukum terdahulu. Artinya ketetapan hukum yang terdahulu tidak berlaku lagi dengan adanya ketetapan hukum yang baru (Dewan Redaksi Enskopedi Islam, p.16) Atas dasar itu, dalil yang datang kemudian disebut nasakh (yang menghapus). Sedangkan hukum yang pertama disebut mansukh (yang terhapus). Sementara itu, penghapusan hukumnya disebut nasakh (Kahar Mansykur, 2002, p.135) Sementara itu, menurut az- 
Zarqani, sebagaimana dinukil Moh. Nur Ichwan, yang dimaksud dengan terminologi "menghapuskan" dalam definisi tersebut adalah terputusnya hubungan hukum yang dihapus dari seorang mukallaf dan bukan terhapusnya subtansi hukum itu sendiri (Moh. Nor Ichwan, 2002, p.108) Definisi diatas apabila dijelaskan lagi, dapat kita tarik beberapa butiran-butiran makna yang tersirat, yakni: Dipastikan terjadi naskh apabila ada dua hal, yaitu nasikh dan mensukh. Nasikh harus turun belakangan dari mansukh, Menilai suatu ayat sebagai pe-naskh dan yang lain di-naskh-kan, apabila ayat-ayat yang kontradiktif itu tidak dapat dikompromikan dan diamalkan secara bersama. ${ }^{3}$ Sedangkan syarat kontradiksi; adanya persamaan subjek, objek, waktu, syarat, dan lain-lain. ${ }^{4}$ Menurut al Qaththan, nasakh ialah mengangkat (menghapus) hukum syara' dengan dalil hukum syara' lain. Kata "hukum" di sini, menunjukkan bahwa prinsip "segala sesuatu hukum asalnya boleh". Kata-kata dengan dalil hukum syara"” mengecualikan pengangkatan (penghapusan)hukum disebabkan kematian atau gila, penghapusan dengan ijma' atau qiyas. (Manna Khalil al-Qattan, 2001, p.285)

Kata nasikh (yang menghapus) maksud Allah seperti firman-Nya dalam surat Al-Baqarah ayat 106 "Dan tidaklah Kami menghapus suatu ayat....". kata itu juga digunakan untuk ayat atau sesuatu yang dengannya nasakh dapat diketahui dan digunakan pula untuk hukum menghapuskan hukum yang lain. Mansukh adalah hukum yang diangkat atau yang dihapus. (Manna
Khalil al-Qattan, 2001, p.286) Perlu dipahami bahwa terjadinya nasikh mansukh itu bukan berarti dalam alQur'an maupun al-Sunnah terdapat kontradiksi, tetapi menunjukkan fleksibilitas ajaran Islam, sehingga bisa disesuaikan dengan situasi dan kondisi sosiokultural penerima ajaran. Oleh sebab itu para ulama ushul menetapkan syarat kemungkinan terjadi nasikh dan mansukh, yaitu :Nasikh harus terpisah dari mansukh, Nasikh harus lebih kuat atau sama kekuatannya dengan mansukh, Nasikh harus berupa dalil-dalil syara', Mansukh tidak dibatasi dengan waktu, Mansukh harus berupa hukum syara', Nasikh wurudnya kemudian setelah mansukh',Disamping itu perlu diketahui bahwa ada Nash-Nash yang sudah pasti yang tidak mungkin dibatalkan, yaitu :

1. Nash yang berisi pokok ajaran, baik berupa aqidah atau pokok-pokok ibadah dan pokok-pokok akhlaq, seperti keadilan, kejujuran, larangan syirik, membunuh, mencuri dan lain sebagainya.

2. Nash yang berisi hukum abadi atau selamanya berdasarkan pernyataan Nash itu sendiri

3. Nash yang berisi pemberitaan satu kejadian baik yang sudah lewat atau yang akan datang (Abdul Wahhab Khalaf, 1968, p.226 - 227)

\section{Syarat-Syarat Mansukh}

Nasikh

Menurut al Qaththan dalam nasakh diperlukan syarat-syarat ; (1) 
Hukum yang dimansukh adalah hukum syara' (2) Dalil penghapusan hukum tersebut adalah khitab syar'i yang datang kemudian dari khithab yang hukumnya dimansukh. (3)Khitab yang dihapus atau diangkat hukumnya tidak terikat (dibatasi)dengan waktu tertentu. Sebab jika tidak demikian maka hukum akan berakhir dengan berakhirnya waktu tersebut. Dan yang demikian itu tidak dinamakan dengan nasakh (Manna Khalil alQattan, 2001, p.285) Sedangkan menurut Abu Anwar memberikan batasan beberapa syarat yang diperlukan dalam nasakh, yaitu : Hukum yang mansukh adalah hukum syara'. Nasakh hanya terjadi pada perintah dan larangan. Nasakh tidak terdapat dalam akhlak, ibadah, akidah, dan juga janji dan ancaman Allah.Dalil yang dipergunakan untuk penghapusan hukum tersebut adalah kitab syar`i yang datang kemudian. Dalil yang mansukh hukumnya tidak terikat atau dibatasi oleh waktu tertentu. Sebab, jika demikian hukum akan berakhir dengan waktu tersebut (Abu Anwar, 2009, p.52) Sebagian ulama ada yang memperluas syaratsyarat terjadi nasakh, yaitu: a.Hukum yang terkandung pada nasikh bertentangan dengan hukum pada mansukh.Yang mansukh harus lebih awal dari Nasikh. Hukum yang di-nasakh mesti hal-hal yang menyangkut dengan perintah, larangan, dan hukuman. Hukum yang di-nasakh tidak terbatas waktu tertentu, mesti berlaku sepanjang waktu. Hukum yang terkandung dalam mansukh telah ditetapkan sebelum munculnya nasikh. Status nash nasikh mesti sama dengan nash mansukh. Maka nash yang zhanni tidak bisa menasakh-kan yang qath' $i$ (Kadar M.Yusuf, 2010117) Nasakh hanya terjadi pada perintah (amr) dan larangan (nahy), baik yang diungkapkan dengan tegas dan jelas maupun yang diungkapkan dengan kalimat berita yang bermaksud perintah atau larangan (khabar bi ma'na al amr aw al nahy), selama tidak berhubungan dengan akidah, zat Allah dan sifat-sifat Allah, kitabkitab Allah, para Rasul, hari kiamat, dan juga tidak terkait dengan etika atau akhlak atau dengan pokokpokok ibadah dan muamalat. (Manna Khalil al-Qattan, p.287) Quraish Shihab, menambahkan lagi syarat nasakh, bahwa nasakh baru dilakukan bila : 1) Terdapat dua ayat hukum yang saling bertolak belakang, serta tidak dapat lagi dikompromikan; 2) Harus diketahui secara meyakinkan urutan turunnya ayat-ayat tersebut. Yang lebih dahulu dikatakan mansukh, dan yang datang kemudian disebut nasakh (Moh. Nor Ichwan, p.146)

\section{Beberapa}

penjelasan mengenai pengertian dan syarat nasakh di atas, dapat disimpulkan Nasakh mempunyai empat rukun yaitu : 1) Nasakh, yaitu proses revisi atau penggantian hukum; 2) Nasakh, yaitu hukum pengganti, dalam hal ini Allah SWT, yang berhak secara mutlak untuk merevisi atau mengganti hukum tersebut; 3) Mansukh, yaitu hukum yang direvisi; dan 4) Mansukh `anhu, yaitu orang yang dikenai hukum atau mukalla (Ishom Elsaha dan Saiful Hadi, 2005, p.555)

\section{Pedoman Nasikh Mansukh}

Pengetahuan tentang nasakh dan mansukh mempunyai fungsi dan 
mafaat besar bagi para ulama, terutama para fuqaha, mufassir dan ahli ushul fikih, agar pengetahuan tentang hukum tidak menjadi kabur. Oleh karena itu, terdapat banyat atsar yang mendorong agar mengetahui masalah ini. Dari Ibnu Abbas, bahwa ia berkata tentang firman Allah ,'Dan barang siapa yang diberi hikmah, sesungguhnya ia telah diberi kebajikan yang banyak." (QS. AlBaqarah :269),"yang dimaksud ialah (yang diberi ilmu tentang nasikh dan mansukh, mutasyabihah, muqaddam dan mu'akharnya serta haram dan halalnya (Manna Khalil al-Qattan, p.288) Untuk mengetahui nasikh dan mansukh ada beberapa cara berikut: Ada keterangan tegas atau pentransimisian yang jelas dari Nabi S.A.W, Konsensus (ijma') umat bahwa ayat ini nasikh dan ayat itu mansukh.Mengetahui mana yang lebih dahulu dan mana yang belakangan berdasarkan histori. Histori ayat dapat diketahui dari keterangan sahabat, yang bukan ijtihad sahabat itu sendiri. Misalkan sahabat itu mengatakan: "Ayat ini turun pada tanggal, bulan atau tahun sekian, sedangkan ayat ini turun pada tanggal, bulan atau tahun sekian, jadi ayat ini lebih kemudian dari ayat itu". Nasikh tidak dapat ditetapkan berdasarkan ijtihad, pendapat mufassir atau kontradiksi dalil-dalil secara lahiriyah atau terlambatnya keislaman salah seorang dari dua perawi. (Manna Khalil al-Qattan, p.288) Ketiga persyaratan itu merupakan faktor yang sangat menentukan adanya nasakh dan mansukh dalam al-Quran. Jadi berdasarkan penjelasan di atas dapat dipahami bahwa nasakh mansukh hanya terjadi dalam lapangan hukum, dan tidak termasuk penghapusan yang bersifat asal (pokok). Sedangkan kedudukan nasakh merupakan salah satu bentuk interpretasi hukum dalam upaya menghadapi ayat atau hadits yang tampak kontradiktif selain dari tarjih atau taksis dalam disiplin ilmu ushul Fiqh. Kuncinya terletak pada soal historis yang menyangkut kedua ketentuan hukum tersebut. Faktor azbabun nuzul ada dalam tingkat ini untuk mengetahui mana ayat yang datang terdahulu dan ayat yang datang kemudian. (Hasan Asyari Ulama I, 2016, p.13) Menurut Yusuf Qardhawi, setidaknya ada tiga kecenderungan dalam masalah nasakh, yaitu : 1) Ada yang meluaskan diri dalam mengklaimadanya nasakh dalam alQuran dan berpendapat bahwa sekian dalam surat sekian dinasakh, sementara tidak ada dalil yang kuat terhadap pe-nasakhan itu; 2) Sebagai antithesis dari mereka, ada yang mengingkari sama sekali adanya nasakh dalam al-Quran; dan 3) Ada pendapat pertengahan yang mengakui adanya nasakh, jika dalil yang sahih dan jelas, yang meyakinkan akal dan menenangkan hati (Yusuf Qardhawi, 1999, p.467)

\section{Pandangan Para Ulama Tentang Nasikh Mansukh}

Pembahasan tentang nasakh dan mansukh yang muncul dalam kajian ilmu tafsir merupakan masalah yang mengandung perdebatan di kalangan para ulama. Kontroversi yang timbul bertolak dari bagaimana memahami dan menghadapi ayat-ayat Al Qur'an yang pada lahirnya kelihatan saling berlawanan. Segolongan ulama 
berpendapat bahwa ada ayat-ayat yang bertentangan dan tidak bisa dikompromikan dan dengan demikian ada nasakh dalam Al Qur'an. Sebaliknya, segolongan ulama lainnya berpendapat bahwa ayat-ayat yang dikatakan tampak bertentangan bisa dikompromikan dan dengan demikian tidak ada nasakh dalam Al Qur'an. (Dewan Redaksi Enskopedi Islam, p.17)

a. kelompok ulama yang mendukung nasakh dan mansukh

Salah satu ayat yang menjadi basis pembangunan teori nasakh adalah firman Allah dalam surat al-Baqarah ayat 106:

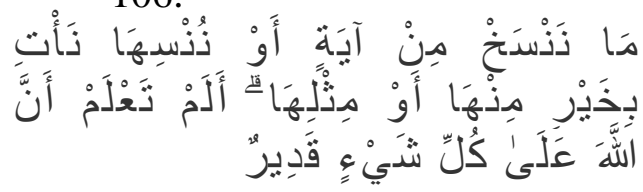

Ayat mana saja yang Kami nasakhkan, atau Kami jadikan (manusia) lupa kepadanya, Kami datangkan yang lebih baik daripadanya atau yang sebanding dengannya.

Tidakkah kamu mengetahui bahwa sesungguhnya Allah Maha Kuasa atas segala sesuat Ayat tersebut dijadikan dasar naqli bagi mayoritas ulama yang mendukung adanya nasakh dalam al-Quran. Mayoritas ulama tanpa keraguan menetapkan ayat-ayat yang termasuk nasakh dan mansukh tetap berlaku, akan tetapi segi hukum yang berlaku menyeluruh sampai waktu tertentu tidak dapat dibatalkan kecuali oleh syara`. Jadi menurut mereka, nasikh mansukh bisa diterima oleh akal dan telah terjadi dalam hukum syara' sesuai dalil di atas. Selain dalil naqli di atas, jumhur ulama pendukung nasakh juga mendasarkan dalil naqli. Mereka berpandangan perbuatan Allah itu mutlak, tidak tergantung pada alasan dan tujuan. Ia boleh saja memerintahkan sesuatu pada suatu waktu dan melarangnya pada waktu yang lain. Ini karena, Allah lebih mengetahui kepentingan hambanya (Manna Khalil al-Qattan, p.331) Pendapat lain yang mendasari mayoritas ulama tentang teori nasakh adalah penetapan perintah-perintah tertentu kepada kaum muslimin di dalam al-Quran yang menurut Rosihan Anwar, ada yang bersifat sementara dan ketika keadaan berubah perintah tersebut dihapus dan diganti dengan perintah baru lainnya. Namun, karena perintahperintah itu kalam Allah, harus dibaca sebagai bagian dari alQuran. (Rosihan Anwar, 2007, p.163) Persoalan nasakh bagi kelompok pendukungnya merupakan salah satu cara menyelesaikan beberapa dalil tersebut. Apabila tidak bisa dikompromikan, salah satunya dinasakh atau dibatalkan. Di samping itu, mereka berpendapat bahwa dalam alQuran secara implisit memang mengandung konsep nasakh. Oleh karen itu jika seseorang ingin menafsirkan al-Quran, menurut M. Abu Zahrah, harus terlebih dahulu mengetahui tentang nasikh dan mansukh (Muhammad Abu Zahrah, 
2008, p.120) Menurut kelompok ini keberadaan nasakh dalam al-Quran selain memiliki dasar dari al-Quran, secara praktis juga nyata dalam sejarah Islam, dan nasakh disebut secara eksplisit di dalam al-Quran. Rachmat Syafe'i memberikan batasan terhadap ayat yang dinasakh, yaitu : (1) ayat al-Quran yang konsekwensi hukumnya saling bertolak belakang dan tidak dapat dikompromikan, (2) harus diketahui secara meyakinkan urutan turunnya ayat-ayat tersebut, yang lebih dahulu ditetapkan sebagai mansukh dan yang datang kemudian sebagai nasikh (Rachmat Syafe'i, 2006, p.94) Jumhur ulama, antara lain Imam Syafi'i mengakui adanya nasakh dalam Al Qur'an. Menurut mereka, ayat yang dinasakh adalah ayat Al Qur'an yang mengandung ketentuanketentuan hukum.disamping alasan nash-nash itu, menurut mereka ada ayat-ayat yang bertentangan dan tidak bisa dikompromikan. (Dewan Redaksi Enskopedi Islam, p.16)

Munawir Sjadzali juga sependapat dengan kelompok yang menyatakan adanya nasakh, sehingga ia menggunakan metode klasik yang disebut dengan nasakh tersebut. Namun dalam praktiknya, Munawir Sadjali menggunakannya dengan cara yang berbeda dengan ulama klasik, sehingga menghasilkan pemahaman yang radikal dan memberikan peran yang luas kepada akal untuk melakukan reinterpretasi terhadap hukum atau petunjuk yang telah diberikan dalam ayat-ayat alQuran dan hadis nabi Muhammad saw. (Munawir Sjadzali , 1997, p.47) Sayyid Quthb dalam tafsirnya "Tafsir fi Zhilal al-Qur'an" berpendapat bahwa ayat 106 dari surat al-Baqarah itu diturunkan sebagai sanggahan terhadap tuduhan orang-orang yahudi bahwa Nabi tidak konsisten, baik mengenai kepindahan kiblat dari masjid al-Aqsha ke Masjid al-Haram, maupun perubahan petunjuk, hukum dan perintah yang terjadi akibat pertumbuhan masyarakat Islam, dan situasi serta kondisi mereka yang terus berkembang (Sayyid Quthb, p.101-102) Berdasarkan paparan di atas, dapat dipahami bahwa nasakh (pergeseran atau pembatalan hukum/petunjuk) itu dapat terjadi tidak hanya pada zaman nabi Muhammad saw. tetapi juga sepeninggal beliau kalau memang kondisi dan situasinya telah berubah. Di samping itu akal budi manusia juga dapat berperan sebagai alat yang dapat menasakh wahyu atau membatalkan/menggeser hukum baik yang termaktub dalam ayat-ayat al-Quran maupun Hadis Nabi saw. selama hal tersebut berkaitan dengan masalah mu'amalah (kemasyarakatan). Dengan demikian, bukan berarti alQuran dan Hadits yang diubah, 
bukan pula syari'at yang diubah, tetapi pengetrapannya yang dapat diubah (Munawir Sjadzali, 1985, p.87) Pandangan Munawir Sadzali, yang menyatakan bahwa nasakh dapat terjadi sepeninggal nabi Muhammad saw., ini jelas-jelas bertentangan dengan ulama yang berpegang pada pandangan klasik yang menyatakan bahwa naskh hanya terjadi pada masa nabi Muhammad saw. atau masa tasyri'. Demikian juga pendapatnya yang membolehkan akal budi (rasio) manusia sebagai alat yang dapat menaskh wahyu Allah bertentangan dengan pendapat umum Ahmad Azhar Basyir, salah seorang tokoh Muhammadiyah misalnya mengatakan bahwa yang berhak menasakh hukumhukum Allah hanya Allah sendiri. Selain Allah tidak berhak menasakh hukumhukum Allah. Setelah al-Quran selesai diwahyukan, nasikh mansukh sudah berhenti. Semua pernyataan fuqaha' dan mufassirin tentang kemungkinan terjadinya nasakh, tertuju pada kurun waktu semasa al-Quran belum selesai diwahyukan. Oleh karenanya jalan nasakh tidak dapat dipergunakan untuk membahas kemungkinan reaktualisasi ajaran Islam, setelah al-Quran diturunkan empat belas abad yang lalu. (Ahmad Azhar Basyir, p.56) Pernyataan senada juga dikemukakan oleh Ali Yafie salah seorang tokoh Nahdlatul Ulama yang menyatakan bahwa perubahan hukumhukum (taghayyur al-ahkam) melalui jalur nasakh terjadi pada tingkat syariah (al-Quran dan Sunnah) saja. Dengan berakhirnya periode tasyri (dengan wafatnya penerima wahyu yaitu Rasulullah saw.) maka perubahan-perubahan hukum Islam melalui jalur nasakh, sudah berakhir juga. Maka merujuk kepada naskh dalam rangka upaya revision of the law dalam hukum Islam tidak pada tempatnya. (Ali Yafie, 1998, p.100) Berdasarkan pernyataan di atas, tampaknya M. Quraish Shihab memperbolehkan adanya pergantian hukum (nasakh) oleh manusia terhadap kasus yang dihadapinya dengan beralih pada ayat hukum yang dianggap cocok sesuai kasus yang dihadapinya. Semua ayat al-Quran tetap berlaku, tidak ada kontradiksi. Yang ada hanya pergantian hukum bagi masyarakat/orang tertentu, karena kondisi yang berbeda. Ayat hukum yang tidak lagi berlaku baginya, tetapi dapat berlaku bagi orang lain yang kondisinya sama dengan kondisi mereka semula (M. Quraish Shihab, p.149-150)

b. Ulama yang menolak nasakh mansukh

Golongan ulama yang menolak adanya nasakh dalam al-Quran berusaha mengkompromikan ayat-ayat yang kelihatan 
bertentangan sehingga tidak perlu dinasakh. Kelompok penolak yang dipelopori oleh Abu Muslim al-Isfahani, menyatakan bahwa dalam alQuran tidak terdapat nasakh. Jika mengakui adanya nasakh berarti mengakui adanya kebatilan dalam al-QuranAbu Muslim al-Isfahani mendasarkan argumentasinya pada al-Quran surat Fushilat ayat 42

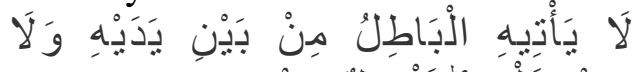

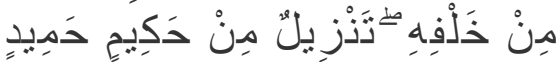

Yang tidak datang kepadanya (Al Quran) kebatilan baik dari depan maupun dari belakangnya, yang diturunkan dari Rabb Yang Maha Bijaksana lagi Maha Terpuji.

Hukum-hukum yang dibawa al-Quran bersifat abadi dan universal. Jadi tidak layak kalau di dalam al-Quran terdapat nasakh. Lebih lanjut abu Muslim al-Isfahani, sebagai mana dikutip Amir Syarifuddin, mengemukakan argumentasi sebagai berikut : Suatu hukum yang ditetapkan oleh Allah SWT adalah karena adanya maslahat atau mafsadat pada sesuatu yang dikenai hukum itu. Sesuatu yang mengandung maslahat tidak mungkin beralih menjadi mafsadat. Kalam itu bersifat qadim, dalam arti telah ada sejak dahulu (azali) sesuatu yang bersifat qadim tidak mungkin dicabut. (Amir Syarifuffin, 2007, p.229) Sehingga jelas, al-Isfahani tidak setuju adanya nasakh. AlIsfahani setuju menginterpretasikan ayat yang secara zhahir terjadi kontradiksi dengan jalan takhsis (pengkhususan), untuk menghindari adanya nasakh atau pembatalan, al-Isfahani berpendapat bahwa pembatalan hukum dari Allah mengakibatkan kemustahilanNya, yaitu : Ketidaktahuan, sehingga perlu mengganti atau membatalkan satu hukum dengan hukum lainnya. b. Jika itu dilakukan Allah, berarti Dia melakukan kesia-siaan dan permainan belaka. (M. Quraish Shihab, p.144) Berbeda dengan al-Isfahani yang cenderung kepada takhsis, Muhammad Abduh menolak adanya nasakh, dalam arti pembatalan, tetapi menyetujui adanya tabdil (dalam pengertian: pengalihan, pemindahan ayat hukum dengan ayat hukum lainnya). Dalam arti bahwa semua ayat al-Quran tetap berlaku, tidak ada kontradiksi. Yang ada hanya pengalihan hukum bagi masyarakat atau orang tertentu, karena kondisi yang berbeda. (Rachmat Syafe'i, 2006, p.88)

Dengan demikian ayat hukum yang tidak berlaku baginya, tetap berlaku bagi orang lain yang kondisinya sama dengan kondisi mereka. Dalam perspektif hikmah, pemahaman semacam ini menurut Quraish Shihab akan sangat membantu dakwah Islamiyah, sehingga ayat-ayat hukum yang bertahap dapat dijalankan oleh mereka yang kondisinya sama dengan kondisi umat Islam pada awal masa Islam. (M. Quraish 
Shihab, p.148) Kendatipun uraian diatas telah dipaparkan, namun terdapat pendapat tentang nasakh, yang dalam masalah ini terbagi pada beberapa golongan: Orang yahudi, menurut mereka naskh tidak bisa diakui, karna naskh mengandung konsep bada', sedangkan bada' adalah muncul setelah tersembunyi. Mereka berpendapat naskh adakalanya tanpa hikmah, dan itu mustahil bagi Allah. Dan adakalanya karna suatu hikmah, tetapi hikmah itu muncul setelah sembunyi, yakni sebelumnya tidak nampak oleh Allah Kalangan Syi'ah Rafidhah, mereka sangat berlebihan dan bahkan memperluas ruang lingkup dalam menetapkan (al Qaththan, p.289-2991) Abu Muslim al Ashfahani, menurutnya naskh secara akal dapat saja terjadi, tetapi menurut syara' naskh tidak bisa terjadi, Jumhur ulama, naskh adalah suatu yang dapat diterima secara akal dan telah terjadi pula dalam hukumhukum syara', berdasarkan dalil-dalil: 1)Perbuatan Allah tidak bergantung pada alasan dan tujuan. Allah boleh saja memerintahkan sesuatu pada satu waktu dan melarangnya pada waktu lain. 2)Nash-nash al Qur'an dan Sunnah menunjuk pada kebolehan nasakh dan terjadinya

Sebenarnya para ahli al Qur'an mengambil sikap yang berbeda-beda terhadap masalah ini. Pertama menolak teori nasakh dengan alasan tidak ada pertentangan antara ketentuan satu ayat dengan ayat lainnya dalam al Qur'an yang tidak dapat diselesaikan dengan cara dikompromikan dengan cara al jami' atau dengan takhsisi. kedua, memodifikasi teori nasakh dalam arti penghapusan dan pembatalan sebab nasakh merupakan penggantian satu syari'at kepada syari'at lain yang lebih sesuai sehingga mudah diterima. Penggantian hukum dengan hukum baru karena disebabkan oleh faktor kondisi dan situasiasi yang memang berbeda. Ketiga, melakukan dekonstruksi teori nasakh. Sikap ini merupakan pengakuan adanya nasakh mansukh dalam al Qur'an. Sikap ini didasarkan pada pemikiran bahwa nasakh merupakan suatu kebenaran historis yang sudah saatnya untuk ditinggalkan.

Ditinggalkan bukan berarti pengingkaran tetapi penghapusan model teori nasakh itulah yang tidak dapat diterima untuk situasi sekarang ini. (Aksin Wijaya, 2009, p.137) Menurut Muhammad Thaha, nasakh bukan penghapusan hukum, melainkan sebagai penundaan hukum sambil menunggu waktu yang tepat. Menurutnya syariat Islam merupakan syariat yang sempurna dan kesempurnaannya terletak pada kemampuannya untuk berkembang. Ia melingkupi potensi-potensi kehidupan masyarakat baik individu 
maupun sosial, dan ia mampu mengarahkan kehidupan tersebut ke dalam tahap-tahap kemajuan yang berlangsung terus-menerus. Kehidupan senantiasa berjalan menuju Allah dalam perjalanan kembalinya. Pertemuan dengan penciptanya merupakan keniscayaan yang telah ditetapkan oleh tahapan syariat yaitu syariah, tariqat dan haqiqat. (Aksin Wijaya, 2009, p.138) Menurut Thaha, perkembangan syariat Islam sebenarnya hanyalah perpindahan dari satu ayat ke ayat lain, dari ayat yang sejalan dengan situasi masa abad VII, beralih kepada ayat yang sejalan atau dianggap lebih tepat untuk kondisi waktu sekarang. Oleh karena itu ketika ayat-ayat Madaniyah yang pada abad VII menasakh ayat-ayat Makkiyah dan telah menjalankan fungsinya tidak layak untuk situasi baru abad XX. Ayat-ayat yang layak untuk situasi sekarang adalah ayat-ayat Makkiyah yang berisi pesan Islam paripurna yang karena situasi dan kondisi ia belum bisa diterima masyarakat Makkah. (Aksin Wijaya, 2009, p.138) Diantara ulama yang menolak Nasakh dan Mansukh dalam Al Qur'an adalah Abu Muslim Asfahami, Imam Ar Razi, Muhammad Abduh, Rashid Redha, Dr. Taufiq Sidqy, Muhammad Khudhari Bek. Alasan penolakan mereka didasarkan pada Surat Al Baqarah ayat 106 ayat yang sama yang digunakan oleh pendukung Nasakh dan Mansukh dengan perbedaan penafsiran. Alasanalasan mereka adalah sebagai berikut : 1) Kandungan Surat Al Baqarah ayat 106 oleh kelompok pendukung Nasakh dan Mansukhdijadikan sebagai argument adanya nasakh dalam Al Qur'an, menurut mereka ditujukan kepada kaum Yahudi yang mengingkari Al Qur'an atau merujuk pada wahyu yang diturunkan sebelum Al Qur'an yang akhirnya digantikan oleh Al Qur'an. Artinya, hukumhukum yang terdapat dalam kitab-kitab suci sebelumnya diganti dengan yang lebih baik yaitu Al Qur'an. Menurut mereka, kalau Al Qur'an benar-benar datang dari Allah swt, maka pasti tidak akan berbeda dari isi kitab-kitab sebelumnya. Untuk itulah Allah menjawab bahwa Dia lebih tahu apa yang maslahat buat hamba-hamba-Nya untuk setiap zaman 2) Jika dalam Al Qur'an ada ayat yang mansukh berarti dalam Al Qur'an berbarti terdapat kesalahan dan saling berlawanan, padahal Al Qur'an sendiri menegaskan : "tidak datang kepada Al Qur'an kebatilan dari depannya maupun dari belakangnya.."(QS.41:42),3)

Rasulullah saw sendiri tidak pernah mengatakan adanya nasakh dalam Al Qur'an. Seandainya ada sudah tentu ia akan menjelaskannya 4) Hadishadis yang dikatakan oleh pendukung nasakh dinilai sebagai penasikh Al Qur'an 
bukanlah hadis mutawatir melainkan hadis ahad yang tidak mempunyai kualifikasi untuk menjadi hujjah dalam menetapkan hukum sesuatu, 5) Dikalangan pendukung nasakh sendiri tidak ada kesepakatan dalam menentukan jumlah ayat-ayat yang mansukh. (Dewan Redaksi Enskopedi Islam, p.18)

Jalan terbaik untuk mengkompromikan kedua kelompok tersebut yaitu dengan jalan meninjau kembali pengertian istilah nasakh yang dikemukakan oleh ulama. Untuk usaha ini, pemikiran Muhammad Abduh dalam menafsirkan ayat-ayat $\mathrm{Al}$ Qur'an dapat dijadikan sebagai titik tolah. Ia menolak adanya nasakh dalam pengertian "pembatalan", tetapi ia dapat menerima dalam pengertian at-tabdil (penggantian/pengalihan/pemin dahan ayat hukum di tempat ayat hukum yang lain). Dengan demikian pengertian istilah nasakh adalah pergantian atau pemindahan dari satu wadah ke wadah yang lain, dalam arti semua ayat Al Qur'an tetap berlaku, tidak ada kontradiktif dan yang dibatalkan. Hanya saja terjadi pergantian hukum bagi masyarakat/orang tertentu karena adanya kondisi yang berbeda. Namun demikian, ayat yang tidak berlaku bagi masyarakat dalam satu kondisi sama dengan kondisi mereka semula. Pemahaman demikian akan sangat membantu dalam pengembangan hukum Islam, sehingga ayat-ayat hukum yang bertahap tetap diberlakukan oleh mereka yang kondisinya sama atau serupa dengan kondisi umat Islam pada awal perkembangan Islam. (Dewan Redaksi Enskopedi Islam, p.19)

Meskipun nasakh mansukh memiliki cakupan yang banyak. Terhadap hal yang demikian ini para ulama memiliki sikap yang berbedabeda : 1) Ada yang berlebihlebihan, sehingga ia memasukkan ke dalam kelompok nasakh sesuatu yang sebenarnya tidak termasuk di dalamnya, 2) Ada yang berhati-hati, dengan mendasarkan masalah nasakh ini hanya pada penukilan yang shahih semata. (Manna Khalil al-Qattan, p.299)

Sumber kekaburan tersebut bagi mereka yang berlebihlebihan, cukup banyak. Yang terpenting diantaranya ialah : Menganggap takhshish juga sebagai nasakh, Menganggap bayan (penjelasan) sebagai nasakh, Menganggap suatu ketentuan yang disyariatkan karena sesuatu sebab yang kemudian sebab itu hilang (dan secara otomatis ketentuan itu pun menjadi hilang) sebagai mansukh. Misalnya perintah bersabar dan tabah terhadap gangguan orang kafir pada masa awal da'wah ketika umat Islam masih lemah dan minoritas. Menurut mereka, perintah itu dihapuskan dengan ayat-ayat perang. Padahal sebenarnya yang pertama, 
yakni kewajiban bersabar dan tabah terhadap gangguan tetap berlaku di saat umat Islam dalam keadaan lemah dan minoritas. Sedang dalam keadaan mayoritas dan kuat, umat Islam wajib mempertahankan akidah melalui perang. Dan itulah hukum kedua yang berdiri sendiri, Menganggap tradisi jahiliyah atau syariat umat terdahulu yang dibatalkan Islam, sebagai nasakh. Misalnya, pembatasan jumlah istri dengan empat dan legalisasi hukum qishas dan diyat, sedang bagi bani Israil hanya berlaku hukum qishas saja, sebagaimana dikatakan Ibnu Abbas sebagaimana yang diriwayatkan oleh Al Bukhari. Hal ini bukanlah nasakh, melainkan pembatalan (alBara'ah Al-Ashliyah) (Manna Khalil al-Qattan, p.230)

\section{Bentuk Dan Macam-Macam Nasakh Dalam Al Qur'an}

Berdasarkan kejelasan dan cakupannya, nasakh dibagi menjadi :

a. Nasakh sharih yaitu ayat yang secara jelas menghapus hukum yang terdapat pada ayat terdahulu. Misalnya ayat tentang perang pada surata al anfal ayat 68

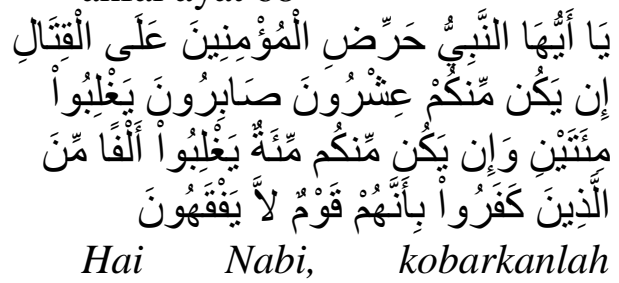
semangat para mu'min untuk berperang. Jika ada dua puluh orang yang sabar diantaramu, niscaya mereka akan dapat mengalahkan dua ratus orang musuh. Dan jika ada seratus orang yang sabar diantaramu, niscaya mereka akan dapat mengalahkan seribu dari pada orang kafir, disebabkan orangorang kafir itu kaum yang tidak mengert

Ayat ini menurut jumhur di nasakh oleh ayat yang mengharuskan satu orang mukmin melawan dua orang kafir pada ayat 66 surat yang sama

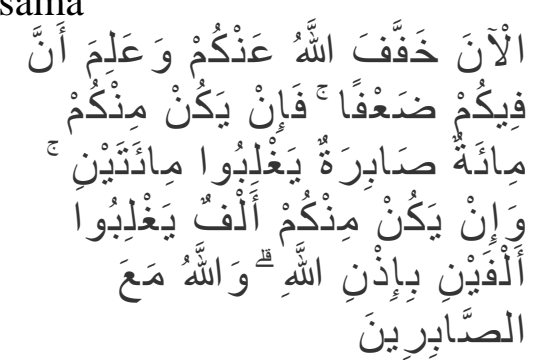

Sekarang Allah telah meringankan kepadamu dan dia telah mengetahui bahwa padamu ada kelemahan. Maka jika ada diantaramu seratus orang yang sabar, niscaya mereka akan dapat mengalahkan dua ratus orang kafir; dan jika diantaramu ada seribu orang (yang sabar), niscaya mereka akan dapat mengalahkan dua ribu orang, dengan seizin Allah. Dan Allah beserta orang-orang yang sabar.

b. Nasakh Dzimmi, yaitu jika terdapat dua nasakh yang saling bertentangan dan tidak dikompromikan dan keduanya turun untuk sebuah masalah yang sama, serta kedua-duanya diketahui waktu turunnya, ayat yang datang kemudian dihapus 
ayat yang terdahulu. Seperti surat al Baqarah ayat 180

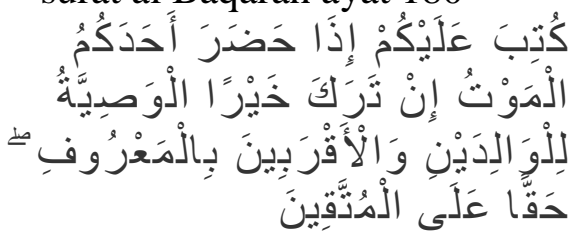

Diwajibkan atas kamu, apabila seorang di antara kamu kedatangan (tanda-tanda) maut, jika ia meninggalkan harta yang banyak, berwasiat untuk ibu-bapak dan karib kerabatnya secara ma'ruf, (ini adalah) kewajiban atas orangorang yang bertakwa.

Ayat ini dinasakh denga hadis yang berbunyi : la washiyyah li waris

c. Nasakh kully yaitu menghapus hukum yang sebelumnya secara keseluruhan. Contohnya ketentuan iddah empat bulan sepeuh hari pada surat al Baqarah 234 di nasakh oleh ketentuan iddah satu tahun pada ayat 240 pada surat yang sama

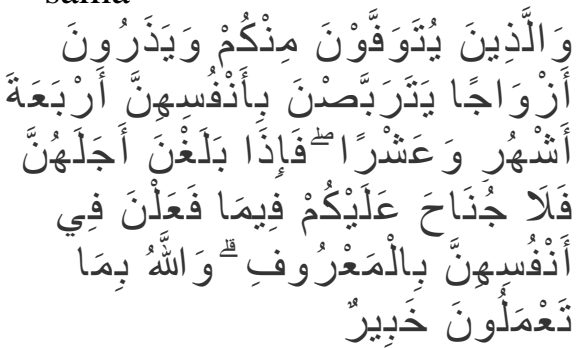

Orang-orang yang meninggal dunia di antaramu dengan meninggalkan isteri-isteri (hendaklah para isteri itu) menangguhkan dirinya (ber'iddah) empat bulan sepuluh hari. Kemudian apabila telah habis 'iddahnya, maka tiada dosa bagimu (para wali) membiarkan mereka berbuat terhadap diri mereka menurut yang patut. Allah mengetahui apa yang kamu perbuat.

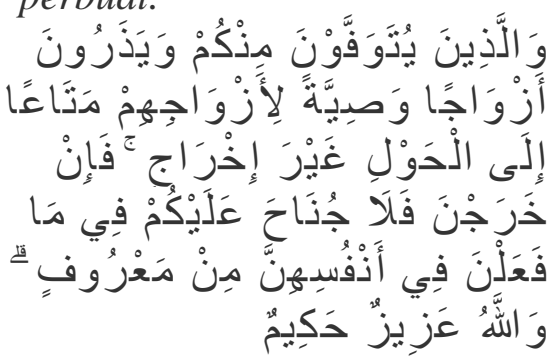

Dan orang-orang yang akan meninggal dunia di antara kamu dan meninggalkan isteri, hendaklah berwasiat untuk isteri-isterinya, (yaitu) diberi nafkah hingga setahun lamanya dan tidak disuruh pindah (dari rumahnya). Akan tetapi jika mereka pindah (sendiri), maka tidak ada dosa bagimu (wali atau waris dari yang meninggal) membiarkan mereka berbuat yang ma'ruf terhadap diri mereka. Dan Allah Maha Perkasa lagi Maha Bijaksana

d. Nasakh Juz'i yaitu menghapus hukum umum yang berlaku bagi semua individu dengan hukum yang hanya berlaku bagi sebagian individu atau menghapus hukum yang bersifat muthlaq . dengan hukum yang muqayyad contoh surat an nur ayat 4 dengan ayat 6 surat yang sama

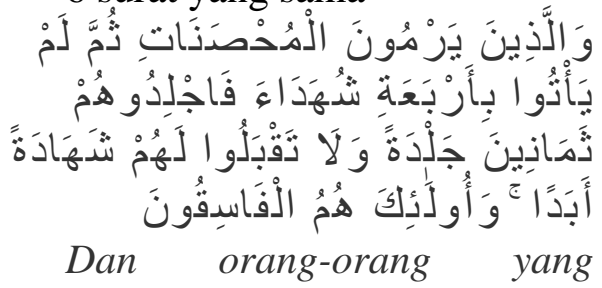
menuduh wanita-wanita yang baik-baik (berbuat zina) dan mereka tidak mendatangkan empat orang saksi, maka 
deralah mereka (yang menuduh itu) delapan puluh kali dera, dan janganlah kamu terima kesaksian mereka buat selama-lamanya. Dan mereka itulah orang-orang yang fasik Ayat tersebut di nasakh dengan ayat 6 pada surat yang sama

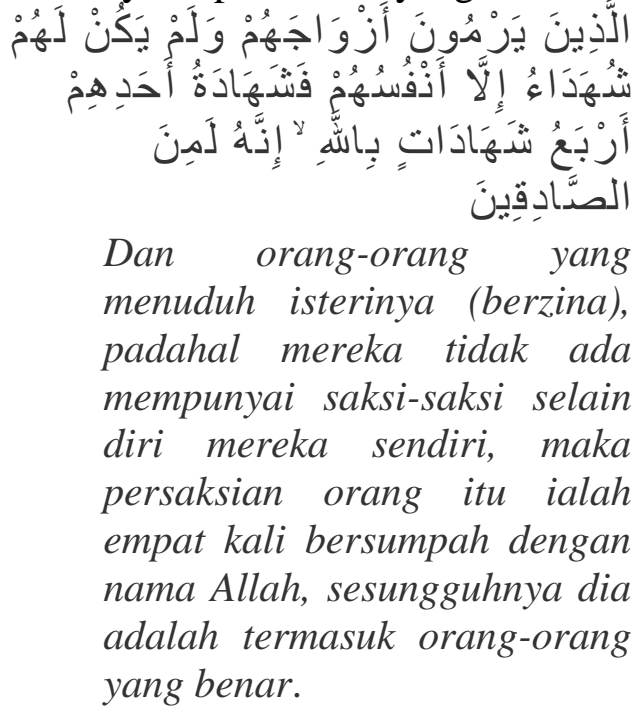

Dan orang-orang yang menuduh isterinya (berzina), padahal mereka tidak ada mempunyai saksi-saksi selain diri mereka sendiri, maka persaksian orang itu ialah empat kali bersumpah dengan nama Allah, sesungguhnya dia adalah termasuk orang-orang yang benar.

Dilihat dari segi bacaan dan hukumnya ulama membaginya menjadi tiga yaitu:

a. Penghapus terhadap hukum dan bacaan (tilawah) secara bersamaan. Ayat- ayat yang terbilang kategori ini tidak dibenarkan dibaca dan tidak dibenarkan diamalkan. Misalnya tentang hadis tentang saudara sesusuan sebanyak sepuluh isapan. Ketetapan ini kemudian dinasakh menjadi lima isapan

b. Penghapusan terhadap hukumnya saja sedangkan bacaannya tetap ada. Contohnya ajakan para penyembah berhala dari kalangan musyrikin kepada umat Islam untuk saling bergantian dalam beribadah, telah dihapus oleh ketentuan ayat qital (peperangan) tetapi bunyi teknya tetap ada

$$
\text { لَكَُمْ دِينُكُمْ وَلِّيَ دِينِ }
$$

Untukmu agamamu, dan

untukkulah, agamaku"

Contoh lainnya tentang sedekah dalam surat mujadilah ayat 12

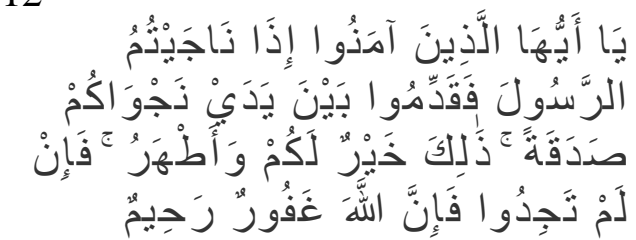

Hai orang-orang beriman, apabila kamu mengadakan pembicaraan khusus dengan Rasul hendaklah kamu mengeluarkan sedekah (kepada orang miskin) sebelum pembicaraan itu. Yang demikian itu lebih baik bagimu dan lebih bersih; jika kamu tidak memperoleh (yang akan disedekahkan) maka sesungguhnya Allah Maha Pengampun lagi Maha Penyayang.

Ayat ini dinasakh dengan ayat 13 surat yang sama

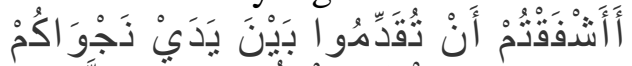

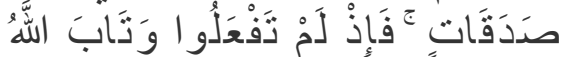

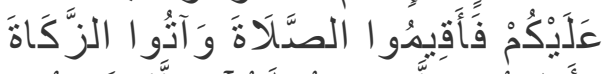

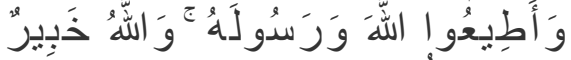

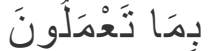

Apakah kamu takut akan (menjadi miskin) karena kamu memberikan sedekah sebelum mengadakan pembicaraan dengan Rasul? Maka jika kamu tiada memperbuatnya dan Allah telah memberi taubat kepadamu maka dirikanlah shalat, tunaikanlah zakat, taatlah kepada Allah dan Rasul-Nya; dan Allah Maha 
Mengetahui apa yang kamu kerjakan.2

c. Penghapusan terhadap bacaannya saja sedangkan hukumnya tetap berlaku

Adapun dari sisi otoritas mana yang berhak menghapus sebuah nasakh para ulama membagi nasakh ke dalam empat macam yaitu :

Nasakh al Qur'an dengan al Qur'an, Nasakh al Qur'an dengan sunnah. Bagi kalangan Hanafiyah nasakh semacam ini diperkenankan bila sunnahnya itu mutawatir atau masyhur. Tetapi pendapat ulama-ulama Hanafiyah ini ditentang oleh mayoritas ulama ushul fiqh. Bagi mereka apap pun jenis sunnah yang akan menghapus ketentuan-ketentuan al Qur'an tetap tidak diperkenankan Nasakh Sunnah dengan al Qur'an. Mayoritas ulama nasakh semacam ini diperkenankan, Nasakh sunnah dengan sunnah. Menurut al Qathtan, pada dasarnya ketentuan nasakh dalam ijma' dan qiyas tidak diperkenankan Persoalan lebih jauh dalam masalah nasikh-mansukh ini ialah soal nasikh-mansukh antara Al Qur'an dengan sunnah. Adanya nasikh mansukh antara satu ayat yang memat ketentuan hukum dalam Al Qur'an dengan lain ayat yang juga memuat ketentuan hukum dalam soal yang sama adalah satu hal yang tidak diperselisihkan lagi. Demikian pula adanya nasikhmansukh antara hadis yang memuat ketentuan hukum dalam soal yang sama merupakan satu hal yang tidak diperselisihkan lagi. Masalah yang menimbulkan perselisihan pendapat diantara para ulama ialah adanya nasikh mansukh silang antara Al Qur'an dengan sunnah. Jika disimak alasan masing-masing yang menjadi perbedaan pendapat ialah pandangan masing-masing tentang kedudukan hirarki Al Qur'an dan sunnah dalam syariat itu sendiri (Sukardi KD, 2002, p.173) Dalam kaitan hirarki Al Qur'an dan sunnah, ada semacam kesepakatan bahwa dalam nasikh-mansukh kedua unsurnya harus sama tingkatnya dan sama nilai dan sifatnya. Jalan pikiran sepeerti ini terdapat juga di kalangan ahli hukum bahwa suatu peraturan hukum tidak dapat dicabut dengan peraturan hukum lainnya yang lebih rendah tingkatannya. Demikian juga lembaga yang mengeluarkanperaturan hukum menjadi factor pertimbangan. Berdasarkan pemikiran ini, ada satu hal yang perlu dicatat bahwa stelah Rasulullah saw wafat, maka tidak ada lagi nasakh-mansukh terjadi pada syariat (Sukardi KD, 2002, p.173)

Jenis nasikh-mansukh yang diuraikan di atas memang segi formalnya. Jenis lain yang menyangkut segi materialnya, ada yang bersifat ekslusif (sharih) dan inklusif (dhanni). Untuk yang bersift eksklusif (sharih), nasikh itu langsung 
menjelaskan mansukhnya. Ketentuan yang nasikh di tetapkan secara jelas seperti halnya contoh dari Al Qur'an di atas. Sedangkan contoh sunah misalnya hukum ziarah kubur. Di dalam hadis disebutkan bahwa Nabi pernah melarang ziarah kubur sekarang diperbolehkan (Sukardi KD, 2002, p.173) Masalah naskh bukalan sesuatu yang berdiri sendiri. Ia merupakan bagian yang berada dalam disiplim ilmu tafsir dan ilmu ushul fiqh. Karena itulah naskh merupakan techniserterm dengan batasan pengertian yang baku. Dalam kaitan ini Imam Subki menerangkan adanya perbedaan pendapat tentang kedudukan naskh : apakah ia berfungsi mencabut (raf) atau menjelaskan (bayan). Ungkapan Imam Subki ini dapat dikaitkan dengan hal-hal yang menyangkut jenis-jenis naskh yang diuraikan di atas. Jika ditinjau dari segi formalnya maka fungsi pencabutan itu lebih nampak. Tapi bila ditinjau dari segi materinya, maka fungsi penjelasannya lebih menonjol. Meski demikian pada akhirnya dapat dilihat adanya suatu fungsi pokok bahwa naskh merupakan salah satu interpretasi hukum. (Sukardi KD, 2002, p.173)

\section{Hikmah Nasakh Mansukh}

Al Maragi dalam kitab tafsirnya melihat adanya hikmah keberadaan nasakh dengan menyatakan :'Sesungguhnya hukumhukum itu tidak diundangkan kecuali untuk kepentingan manusia. Hal ini dapat berbeda karena perbedaan waktu dan tempat. Jika suatu hukum diundangkan karena dirasakan perlu adanya hukum itu, kemudian keperluan itu berakhir, maka adalah suatu tindakan bijaksana menghapuskaan hukum itu dan menggantikannya dengan hukum yang lebih sesuai dengan waktu itu. Dengan demikian hukum menjadi lebih baik dari yang semula atau sama dari segi manfaat untuk hamba-hamba Allah."(Dewan Redaksi Enskopedi Islam, p.17) Manna Khalil al-Qattan menjelaskan tentang hikmah adanya nasakh dalam al-Quran, yaitu : 1) Menjaga keselamatan hamba Allah; 2) Perkembangan tasyri` menuju tingkat sempurna sesuai dengan perkembangan dakwah dan perkembangan kondisi umat Islam; 3) Cobaan dan ujian bagi Mukallaf untuk mematuhinya atau sebaliknya; dan 4) menghendaki kebaikan dan kemudahan bagi umat Islam. Sebab jika nasakh itu beralih kepada hal atau perkara yang lebih berat maka di dalamnya terdapat tambahan pahala, dan jika beralih kepada hal atau perkara yang lebih ringan maka nasakh mengandung kemudahan dan keringanan. (Manna Khalil al-Qattan, p.338)

\section{Kesimpulan}

Nasakh

adalah

menghilangkan, menghapuskan, membatalkan ayat dengan ayat yang lain karena adanya dalil yang menunjukkannya. Nasakh terjadi pada ayat yang berlawanan atau kontradiksi dengan ayat yang lain 
yang sulit untuk dikompromikan. Nasakh dan mansukh hanya berlaku terhadap ayat-ayat yang berkaitan dengan hukum syar'i yaitu terjadi pada perintah dan larangan. Nasakh tidak terdapat dalam akhlak, ibadah, akidah, dan juga janji dan ancaman Allah

Berkaitan dengan nasakh dan mansukh dikalangan ulama terdapat dua kelompok yang berseberangan. Pertama, golongan ulama yang menerima dan mendukung terjadinya nasakh dan mansukh. Kedua, golongan ulama yang menolak terjadinya nasakh dan mansukh. Terhadap kedua kelompok yang berbeda pendapat ini, diperlukan kompromi karena perbedaan kedua golongan ini memiliki implikasi terhadap ketetapan hukum yang dibutuhkan oleh masyarakat. Kompromi tersebut dilakukan dengan meninjau kembali istilah nasakh dan mansukh yang digunakan oleh ulama. Pemikiran Muhammad Abduh, mungkin dapat dijadikan jalan tengah terhadap perbedaan pendapat tersebut, meskipun Muhammad Abduh termasuk golongan yang menolak nasakh mansukh. Pemikiran tersebut adalah mengubah istilah nasakh mansukh sebagai

penggantian/pengalihan/pemindahan ayat hukum di tempat ayat hukum yang lain.

Adapun bentuk-bentuk nasakh dan mansukh meliputi (1) Nasakh sharih (2) Nasakh Dzimmi (3) Nasakh kully (4) Nasakh Juz'i. Sedangkan otoritas mana yang berhak menghapus sebuah nasakh para ulama membagi nasakh ke dalam empat macam yaitu (1) nasakh al Qur'an dengan al Qur'an (2) nasakh al Qur'an dengan sunnah (3) nasakh Sunnah dengan al Qur'an (4) nasakh sunnah dengan sunnah

\section{Daftar Pustaka}

Aksin Wijaya, 2009, Arah Baru Studi Ulum Al-Qur'an : Memburu Pesan Tuhan di Balik Fenomena Budaya, Yogyakarta, Pustaka Pelajar

Al-Qattan , Manna Khalil, 2001, Studi Ilmu-ilmu al-Quran, terj. Mudzakir, Yogyakarta : Pustaka Lentera

Amir Syarifuffin, 2007, Ushul Fiqh, jilid I, Jakarta : Logos Wacana Ilmu

Anwar, Abu, 2009, Ulumul Quran, Sebuah Pengantar, Yogyakarta : Amzah

Anwar, Rosihan, 2007, Ulumul Quran, Bandung : Pustaka Setia

Basyir, Ahmad Azhar, 1998, "Reaktualisasi, Pendekatan Sosiologis Tidak Selalu Relevan", dalam Iqbal Abdurrauf Saimima (ed.), Polemik Reaktualiasi Ajaran Islam, Jakarta: Pustaka

Dewan Redaksi Enskopedi Islam, 1997, Ensiklopedi Islam, Jakarta, Ictiar Baru Van Hoeve

Elsaha, Ishom dan Hadi, Saiful, 2005, Sketsa al-Quran : Tempat, Tokoh, Nama dan Istilah dalam al-Quran, Jakarta : Lista Fariska

Hasan Asyari Ulama'I, 2016, Konsep Nasikh Dan Mansukh Dalam Al-Quran, Jurnal Didaktika Islamika Volume 7 Nomor 1 Pebruari 
Ichwan, Moh. Nor, 2002, Studi IlmuIlmu al-Quran, Semarang : RaSail Media Group

Khalaf, Abdul Wahhab, 1968, Ilmu Ushul Fiqh, ttp: Dar alKuwaitiyyah

Lihat, Jalaluddin Rahmat dkk. 2002, Belajar Mudah 'Ulum AlQur'an : Studi Khazanah Ilmu Al-Qur'an, Editor : Sukardi KD Jakarta, Lentera

Mansykur, Kahar, 2002, Pokokpokok Ulumul Qur'an, Jakarta : Rineka Cipta

Qardhawi , Yusuf, 1999, Berinteraksi dengan alQuran, Jakarta : Gama Insani Press

Quthb , Sayyid, Tafsir fi Zhilal alQur'an, Beirut: Dar alArabiyyah, t.th

Rachmat Syafe'i, 2006, Pengantar Ilmu Tafsir, Bandung : Pustaka Setia

Shihab, Quraish, 1994, Membumikan al-Qur'an Bandung : Mizan

Shihab, Quraish, 2004, Membumikan al-Quran, Fungsi dan Peran Wahyu dalam Kehidupan, Bandung : Mizan

Sjadzali, Munawir, 1985, PokokPokok Kebijaksanaan Menteri Agama dalam Pembinaan Kehidupan Beragama, Jakarta: Depag RI,

Sjadzali , Munawir, 1997, Ijtihad Kemanusiaan., Jakarta : Paramadina

Syafe`i , Rachmat, 2006, Pengantar Ilmu Tafsir, Bandung : Pustaka Setia

Taufiq, Imam. 2001, Maqamat dan Ahwal, Tinjauan Metodologis, dalam Tasawuf dan Krisis, Yogyakarta :
Pustaka Pelajar bekerja sama dengan IAIN Walisongo Press,

Yafie, Ali, 1998, Antara Ketentuan dan Kenyataan?, dalam Iqbal Abdurrauf Saimima (ed.), Polemik Reaktualiasi Ajaran Islam, Jakarta: Pustaka Panjimas

Yusuf, Kadar M., 2010, Studi al Qur'an, Jakarta: Amzah

Zahrah, Muhammad Abu, 2008, Ushul Fiqih, terj. Saefullah Ma`sum, dkk, Jakarta : Pustaka Firdaus 